\title{
IS That All There Is? The Dubious DiVIDENDS OF DANIELS
}

\author{
KERRY WILKINS*
}

\section{INTRODUCTION}

In 1999, representative Métis and non-status Indians brought proceedings in the Federal Court seeking clarification of their constitutional status. Why? Because, as their counsel explained much later to the Supreme Court of Canada,

[t]he record is replete with references to the comparative disadvantage that Métis and non-status Indians face, "lacking even the protection of the Department of Indian Affairs"... [T] he socio-economic needs of Métis and non-status Indians were comparable to those of the registered Indian population, but ... they did not have access to federal programs and services to ameliorate those needs. Nor were they able to exercise their aboriginal rights in the same manner as status Indians, have their treaty rights recognized, participate in the specific claims process, or negotiate with the federal government over their needs, rights, and interests as Aboriginals. ${ }^{1}$

As relief, they sought three declarations: (1) that Métis and non-status Indians are "Indians" within federal legislative authority, pursuant to section 91(24) of the Constitution Act, $1867^{2}$ (the first declaration); (2) that the federal Crown owes fiduciary duties to Métis and non-status Indians as Aboriginal peoples (the second declaration); and (3) that the federal Crown has a duty to consult and negotiate in good faith on a collective basis with these peoples "through representatives of their choice respecting their rights, interests and needs as Aboriginal peoples" (the third declaration). ${ }^{3}$

Seventeen years later, in Daniels $v$. Canada, ${ }^{4}$ the Supreme Court granted the first declaration requested. "Non-status Indians and Métis," it said, "are 'Indians' under s. 91(24) and it is the federal government to whom they can turn."

Make no mistake. This was a case the federal Crown deserved to lose, for at least two reasons. First, its principal position throughout was that the courts should refuse to consider Daniels because the declarations requested would have no practical utility, make no practical difference. The trial judge and the Federal Court of Appeal used 36 and 15 paragraphs, respectively, of their reasons for judgment reviewing (and rejecting) federal submissions to

* Adjunct Professor, Faculty of Law, University of Toronto. Sincere thanks to John Borrows, Kent McNeil, Joshua Nichols, Candice Telfer (especially), and the Alberta Law Review's anonymous reviewers for helpful comments and suggestions on earlier drafts. Remaining infelicities are my fault alone, not theirs.

1 Daniels $v$ Canada (Indian Affairs and Northern Development), 2016 SCC 12 [Daniels SCC] (Appellants' Factum at para 30 [footnotes omitted], online: <www.scc-csc.ca/WebDocumentsDocumentsWeb/35945/FM010_Appellants_Harry-Daniels-et-al.pdf $>$ ).

2 (UK), 30 \& 31 Vict, c 3, s 91(24) (assigning to the federal order of government exclusive legislative authority over "Indians, and Lands reserved for the Indians").

3 Appellants' Factum, supra note 1 at paras 2, 7.

4 Daniels SCC, supra note 1, aff'g in part 2014 FCA 101 [Daniels FCA], aff'g in part 2013 FC 6 [Daniels FC].

Daniels SCC, ibid at para 50. 
that effect. ${ }^{6}$ Even at the Supreme Court, which had deemed Daniels to have sufficient public importance ${ }^{7}$ to belong among the 13 percent of cases given leave to appeal, ${ }^{8}$ Canada spent 32 (over 20 percent) of its factum paragraphs renewing that same entreaty. ${ }^{9}$

Such submissions, with due respect, were not altogether credible. On at least four occasions, Canada actively sought to prevent Daniels from getting to trial, ${ }^{10}$ spending on those efforts, according to the trial judge, between $\$ 5$ and $\$ 6$ million of public money. ${ }^{11}$ No rational litigant would spend such resources to block a case whose outcome it thinks would make no practical difference.

Neither were the federal submissions substantively persuasive. Canada opposed consideration of the first declaration in Daniels because, it said, such adjudication would take place in a "legislative vacuum": because the plaintiffs did not contest the constitutional soundness of any particular federal or provincial legislation. "The Court's role" in division of powers jurisprudence, Canada insisted, "is to determine whether statutes or proposed statutes are validly enacted, not to define the outer limits of constitutional authority in the abstract. Abstract answers interfere with the free exercise of the legislative function by preempting its operation." ${ }^{13}$ But the "legislative vacuum" in Daniels was precisely the problem in need of attention. It resulted, as both the Supreme Court ${ }^{14}$ and the trial judge ${ }^{15}$ pointed out, because neither order of government (federal or provincial) showed much interest in (taking the risk of) enacting legislation about Métis or non-status peoples. Circumstances such as this, where protracted constitutional indifference or uncertainty has paralyzed government response, seem, if anything, specially deserving of judicial resolution. And how or why, exactly, do "[a]bstract answers interfere with the free exercise of the legislative function by pre-empting its operation"? No obligation to legislate results from clarification of federal

Daniels FC, supra note 4 at paras 48-83; Daniels FCA, supra note 4 at paras 65-79. The Federal Court of Appeal agreed with Canada (ibid at paras 74-79) that there would be no practical utility in determining whether non-status Indians are section 91(24) Indians. The Supreme Court reversed (Daniels SCC, ibid at para 20).

7 The statutory test for leave is whether "the Supreme Court is of the opinion that any question involved therein is, by reason of its public importance or the importance of any issue ... involved in that question, one that ought to be decided by the Supreme Court or is, for any other reason, of such a nature or significance as to warrant decision by it" (Supreme Court Act, RSC 1985, c S-26, s 40(1)). According to more than one commentator, "the public importance of the proposed appeal to the development of the law is the paramount consideration in the leave decision" (Geoff R Hall, "Applications for Leave to Appeal: The Paramount Importance of Public Importance" (1999) 22:1 Adv Q 87 at 90, citing with approval John Sopinka \& Mark A Gelowitz, The Conduct of an Appeal (Toronto: Butterworths, 1993) at 166-67).

8 "Of the approximately 600 leave applications submitted each year, only about 80 are granted" ("Important information about seeking leave to appeal to the Supreme Court of Canada," online: <www. scc-csc.ca/unrep-nonrep/app-dem/important-eng.asp $\mathrm{x}>$ ).

Daniels SCC, supra note 1 (Factum of Respondents on Appeal and Factum of Appellants on CrossAppeal at paras 41-72, online: <www.scc-csc.ca/WebDocuments-DocumentsWeb/35945/FM020

Respondents_Her-Majesty-the-Queen-as-represented-by-The-Minister-of-Indian-Affairs-and-NorthernDevelopment-et-al.pdf $>$ [Federal Factum]).

Harry Daniels v HMQ, 2002 FCT 295 (attempting to strike the claims); Harry Daniels v Her Majesty the Queen, 2005 FC 699, aff'd 2005 FC 1109 (opposing plaintiffs' motion to substitute additional plaintiffs on the death of an original plaintiff, Harry Daniels); Harry Daniels v Her Majesty the Queen, 2008 FC 823 (trying again to strike the claims \& contesting the Federal Court's jurisdiction to hear them); Daniels v R, 2011 FC 230 (opposing plaintiffs' application for an advance costs order to support the litigation after federal Test Case Funding Program funding ran out).

Daniels FC, supra note 4 at para 79.

Federal Factum, supra note 9 at paras 41, 46, 50.

Ibid at para 47 [footnotes omitted].

Daniels SCC, supra note 1 at para 15.

Daniels FC, supra note 4 at para 69. 
legislative authority. ${ }^{16}$ And legislatures have no greater freedom to legislate before than after appropriate judicial determination about the scope of their legislative authority. Ignorance of latent limits on one's authority is not the same thing as freedom. Where, as in Daniels, the constitutional impasse results, at least in part, from doubt about the proper locus of the relevant legislative authority, surely a judicial determination of that issue, even if "abstract," would serve to liberate, not interfere with, its exercise.

The first declaration does have practical utility. Everyone has an interest in ensuring that legislation that governs us emanates from the right, not from the wrong, order of government. ${ }^{17}$ Preserving and protecting that interest requires that courts continue to ascertain authoritatively which order of government may legislate about what.

But there is another, more important reason why Canada deserved to lose in Daniels. What prompted the prayer for the first declaration was Canada's insistence that it could not negotiate the claims of Métis or non-status peoples, include them in the programs and services offered to status Indians, or provide them with comparable parallel programs or services because it lacked legislative authority over them. ${ }^{18}$ The Daniels plaintiffs sought to deprive the federal Crown of this excuse for its unresponsiveness.

This ought to have been unnecessary. We have known since at least the 1920s that both orders of government may use their own resources - their spending power, as it is usually called - to achieve consensually results they lack legislative authority to compel unilaterally. ${ }^{19}$ It is true that both need some statutory authority to spend public money, ${ }^{20}$ but as long as the legislation authorizing the expenditure is really about the allocation of federal (or, as the case may be, provincial) resources, the federal (or provincial) Crown may use or distribute those resources pretty much as it chooses, ${ }^{21}$ subject only, today, to section 15 of the Canadian Charter of Rights and Freedoms. ${ }^{22}$ No matter what we say about federal legislative authority, Canada has, and always has had, all the constitutional capacity it needs to design targeted programs for, and deliver them to, Métis and non-status Indians, or to

16 Daniels SCC, supra note 1 at para 15

17 See e.g. Nova Scotia (AG) v Canada (AG) (1950), [1951] SCR 31 at 34; Thorson v Canada (AG) (1974), [1975] 1 SCR 138.

18 Daniels SCC, supra note 1 at paras 13 (both), 20 (non-status Indians); Daniels FC, supra note 4 at para 55 .

19 Compare Brooks-Bidlake v British Columbia (AG), [1923] 2 DLR 189 (PC) (province may enforce condition in Crown timber licence prohibiting employment of Chinese or Japanese workers) with British Columbia $(A G) \vee$ Canada (AG), [1923] 4 DLR 698 (PC) (but provision in provincial legislation authorizing inclusion of such conditions in provincial Crown timber licences is inoperative). See also British Columbia (AG) v The Deeks Sand \& Gravel Co Ltd, [1956] SCR 336 (province may enforce compromise concerning payment of Crown royalties even without legislative authority to require payment of the royalties); Re Exported Natural Gas Tax, [1982] 1 SCR 1004 at 1032, dissenting, but not on this point (province "may do as a proprietor (absent federal legislation) what it might not be able to do as a legislator"); Four B Manufacturing Ltd v United Garment Workers, [1980] 1 SCR 1031 at 1050 [Four B] ("[t]he Government of Canada subsidizes a great many industries without Parliament thereby acquiring the power to regulate their labour relations").

20 Auckland Harbour Board v The King (New Zealand), [1923] UKPC 92; Commercial Cable Co v Government of Newfoundland (1916), 29 DLR 7 (PC); New South Wales v Bardolph, [1934] HCA 74.

21 Smylie $v$ The Queen (1900), 27 OAR 172; YMHA Jewish Community Centre of Winnipeg Inc v Brown, [1989] 1 SCR 1532.

22 Part I of the Constitution Act, 1982, being Schedule B to the Canada Act 1982 (UK), 1982, c 11 [Charter]. 
include them in current or future programs aimed at status Indians. The federal Crown acknowledged this in its Supreme Court materials. ${ }^{23}$

The same is true, for the most part, of the federal Crown's capacity to negotiate treaties or other agreements with Métis or non-status Indians that address their interests, needs, or claims of right. Federal discretion to offer programs and services includes the power to reach agreement with the intended recipients on appropriate terms and conditions. ${ }^{24}$ And because the Crown has, among other things, all the powers of a natural person, it has, when faced with a claim of right from a Métis or non-status group, at least the same range of options as anyone else would have when faced with an adverse claim. It can consider the claim on its merits and, depending on its view of the merits, stop doing what it is alleged to be doing that interferes with the right, negotiate a consensual resolution of the claim (involving appropriate compensation or consideration), or ignore or defend the claim and take its chances in court. None of these common law options requires any particular view of federal legislative authority. ${ }^{25}$ It is true that the federal order cannot unilaterally set aside provincial Crown

Federal Factum, supra note 9 at para 69 [footnotes omitted]:

The programs and services that the federal Crown provides to registered Indians are most often provided under the spending power, not as a result of the exercise of Parliament's s. 91(24) jurisdiction. The programs and services that federal or provincial governments provide under the spending power, whether to Aboriginal people or others, are not restricted or determined by the divisions of powers provisions of the Constitution".

Federal counsel were coy about Canada's earlier disclaimers of capacity to address the claims, needs, and interests of non-status and Métis peoples. "That may have been the thinking of particular civil servants at the time," they acknowledged, "but ... legislative jurisdiction over Indians is a relatively insignificant factor in relation to the issues at play. Moreover, an erroneous understanding of constitutional law on the part of civil servants should not be the basis for the determination of a division of powers question" (ibid at para 72).

Reference re The Employment and Social Insurance Act (Canada), [1936] SCR 427 at 457 ("it is evident that the Dominion may grant sums of money to individuals or organizations and that the gift may be accomplished by such restrictions and conditions as Parliament may see fit to enact. It would then be open to the proposed recipient to decline the gift or to accept it subject to such conditions"), aff'd [1937] 1 DLR 684 (PC).

25 Parliament does exercise legislative authority when it makes special statutory rules that pertain exclusively to claims brought against the federal Crown; the Crown Liability and Proceedings Act, RSC 1985 , c C-50, as amended, is the obvious example. But the capacity to enact such legislation does not derive from, or depend upon the scope of, its legislative authority under section 91(24) of the Constitution Act, 1867. It is, at a minimum, arguable that the validity of the federal Specific Claims Tribunal Act, SC 2008, c 22 [SCTA], does not depend on section 91(24). That tribunal's mandatory jurisdiction extends only to claims against the federal Crown. It may assume jurisdiction over a province only if "the province certifies in writing that it has taken the steps necessary for it to be bound by decisions of the Tribunal" (SCTA, s 23(2)-(3)). The one thing for which the federal order might require resort to section 91(24) in consensual claims resolution is the enactment of enabling legislation implementing treaties or agreements with Indigenous peoples located within provincial territory: see Daniels SCC, supra note 1 (Factum of the Intervener, Métis National Council at para 10 [MNC Factum], online: <www.scc-csc.ca/WebDocuments-DocumentsWeb/35945/FM100_Intervener_M\%E9tisNational-Council.pdf $>$ )>. 
lands for the exclusive use of Métis or non-status peoples to settle their claims or otherwise, ${ }^{26}$ but confirmation of federal legislative authority over them would not change that. ${ }^{27}$

Canada put its legislative authority into dispute when it masked as incapacity its lack of interest in addressing non-status and Métis peoples' interests, needs, and claims of right. It deserved to have its bluff called. In that respect, justice was done.

In other respects, however, the Daniels decision is disappointing, for its reasoning, its obscurity, and the poverty of its results. Although it makes intuitive sense to classify Métis and non-status peoples as "Indians" for division of powers purposes, the reasoning the Supreme Court gives for doing so is, as Part II explains, weak and unpersuasive. Part III discusses what Daniels actually decided: whether it situates non-status Indians and Métis within exclusive federal legislative authority, and what difference this makes. Part IV considers how much Daniels really does to help the plaintiffs ameliorate what the Supreme Court itself has described as "an inadequate status quo." ${ }^{28}$ Unfortunately, in my judgment, it has not done as much as it could, or should, have done. Part V summarizes and concludes.

\section{THE REASONS}

The Supreme Court saw no need to substantiate its conclusion that non-status Indians are "Indians" for the purposes of section 91(24) of the Constitution Act, 1867 because, it said, the federal Crown had properly conceded the point, "a concession," it said, "that reflects the fact that the federal government has used its authority under s. 91(24) in the past to legislate over non-status Indians as 'Indians." ${ }^{29}$ This proposition, of course, assumes that the federal order has authority under section 91(24) to be used in this way and for this purpose: the very point that, till then, had been in dispute. A similar assumption appears, as we shall see, in the reasoning offered to support the (contested) conclusion that Métis too are "Indians" under section 91(24). ${ }^{30}$ There may well be other, better reasons for acknowledging federal legislative authority over non-status Indians — we know, for example, that Inuit are

Canada's natural resources transfer agreements with the prairie provinces require those provinces to set aside, at Canada's request, such further parcels of unoccupied Crown land as they agree may be "necessary to enable Canada to fulfil its obligations under the treaties with the Indians of the Province" (Constitution Act, 1930 (UK), 20 \& 21 Geo V, c 26 (UK), Schedule 1 (Manitoba), para 11; ibid, Schedules 2-3 (Alberta and Saskatchewan, respectively), para 10). This will not assist Canada in addressing Métis' land claims in those provinces, because Métis are not "Indians" for purposes of these arrangements ( $R v$ Blais, 2003 SCC 44 [Blais]). It may, however, provide some flexibility in addressing claims from non-status Indians in those provinces. Courts have yet to decide whether non-status Indians are "Indians" for purposes of those agreements.

27 Constitution Act, 1867, supra note 2, ss 108-109 (provincial Crowns hold underlying title to most Crown lands within their boundaries, subject to other pre-existing interests); St. Catherine's Milling \& Lumber Company v The Queen (Ontario), [1888] UKPC 70 at 4-13; Ontario Mining Co Ltd v Seybold (1902), [1903] AC 73 (PC) at 79, 82 [Seybold] (surrender to federal Crown of Indigenous interest in lands in a province confers no proprietary interest in that land on federal Crown: it removes an encumbrance on underlying provincial Crown title); Seybold, ibid at 79 (only provincial Crown may dispose of Crown lands in a province), 82; Wewaykum Indian Band v Canada, 2002 SCC 79 at para 15; Williams Lake Indian Band v Canada (Aboriginal Affairs and Northern Development), 2018 SCC 4 at para 76 (federal Crown may not appropriate provincial Crown lands to create reserves for Indians). Daniels SCC, supra note 1 at para 15 .

Ibid at para 20. By way of example, it cited the federal decision to incorporate into the Indian Act, many Indigenous peoples from Newfoundland and Labrador who before that province joined Confederation in 1949 could not possibly have qualified as "Indians" under Canadian legislation (Daniels SCC, ibid at $n$ 2).

30 See notes $48-53$ below and accompanying text. 
“Indians" under section $91(24)^{31}$ despite lacking status under the Indian Act ${ }^{32}$ — but such reasons might require attention to questions of definition and identification that the Daniels decision chose to leave unaddressed. ${ }^{33}$

Because the federal Crown did not concede federal legislative authority over Métis, the Supreme Court's conclusion confirming federal authority required substantiation. The decision offered four explanations for that conclusion: (1) that without legislative authority over all Aboriginal groups, Canada could not have extended the railway, or settlement, westward; (2) that Canada has sometimes assumed, and acted on the assumption, that it has constitutional authority over Métis as Indians; (3) that it would be "constitutionally anomalous" for Métis to be the only Indigenous peoples mentioned in section 35(2) of the Constitution Act, 1982 who were not section 91(24) Indians; and (4) that the federal order needs legislative authority over all Indigenous peoples to realize its goal of reconciliation with them all. None of these arguments, in my judgment, persuades.

\section{A. WESTWARD EXPANSION}

The Supreme Court agreed with the trial judge that "expanding British North America across Rupert's Land and the North-West Territories was a major goal of Confederation[,] ... that building a national railway was a key component" and that a "good relationship with all Aboriginal groups was required to realize" this goal. ${ }^{34}$ So far, so good. But "[o]nly by having authority over all Aboriginal peoples," the Daniels decision continued, "could the westward expansion of the Dominion be facilitated." 35 Accordingly, it concluded, the term "Indians" in section 91(24) must have "meant all Aboriginal peoples, including Métis." 36

Not necessarily, for at least two reasons. First, at the relevant times, Canada, for reasons unrelated to section 91(24), had constitutional authority over everyone, including "all Aboriginal peoples," in Rupert's Land and the North-West Territories. ${ }^{37}$ Apart from the original "postage stamp" province of Manitoba, which assumed its full current size only in $1912,{ }^{38}$ there were until 1905 no provinces in that territory equipped with competing legislative authority. ${ }^{39}$ Federal authority over Canadian territory outside provincial boundaries was (and is) plenary unless and until the federal order has decided to create new provinces there. ${ }^{40}$ Second, in places such as Manitoba and British Columbia, where there came to be independent provincial capacity, Canada's exclusive legislative authority over

\footnotetext{
31 Reference as to whether "Indians" in s 91(24) of the BNA Act includes Eskimo Inhabitants of the Province of Quebec, [1939] SCR 104 [Reference re Eskimo].

RSC 1985, c I-5, s 4(1).

See Daniels SCC, supra note 1 at paras $17-19$. See also notes $72-81$ below and accompanying text.

Daniels SCC, ibid at para 25.

Ibid [emphasis in original].

Ibid.

Federal, Alberta, and Saskatchewan counsel pointed this out in their written submissions to the Supreme Court in Daniels SCC. See Federal Factum, supra note 9 at paras 4, 152; Daniels SCC, supra note 1 (Factum of the Intervener, the Attorney General of Alberta at para 10, online: <www.scc-csc.ca/ WebDocuments-DocumentsWeb/35945/FM050 Intervener Attorney-General-of-Alberta.pdf $>$ ); Daniels SCC, ibid (Factum of the Intervener, Attorney General for Saskatchewan at para 11, online: $<$ www.scccsc.ca/WebDocuments-DocumentsWeb/35945/FM040_Intervener_Attorney-General-forSaskatchewan.pdf $>$ ).

The Manitoba Boundaries Extension Act, 1912, 2 Geo V, c 32.

Alberta Act, 4 \& 5 Edw VII, 1905, c 3; Saskatchewan Act, 4 \& 5 Edw VII, 1905, c 42.

Constitution Act, 1871 (UK), 34 \& 35 Vict, c 28, ss 4, 2 (respectively).
} 
interprovincial railways, criminal law and procedure, and defence and military matters, ${ }^{41}$ together with its extraordinary residual power to deal with apprehended national emergencies, ${ }^{42}$ gave it ample capacity, altogether apart from section 91(24), to keep the peace, facilitate settlement, and complete and protect the national railway. Section 91(24), then, was unnecessary to the realization of these crucial early national aspirations; in respect of them, it need not have existed at all. As a result, they have nothing helpful to tell us about what "Indians" means in section 91(24). ${ }^{43}$

\section{B. Previous Federal Practice, And Assumptions}

"Before and after Confederation," the Supreme Court tells us in Daniels, "the government frequently classified Aboriginal peoples with mixed European and Aboriginal heritage as Indians"; ${ }^{4}$ after Confederation, the federal order sometimes "legislated over Métis as 'Indians." "45 This is true enough, but how does it help us determine what "Indians" means in section $91(24)$ ?

One might regard these pre- and early post-Confederation instances as evidence of what "Indians" meant at the time of Confederation, and therefore of the intention of the framers who chose that term in prescribing the scope of federal legislative authority. To those who consider framers' intentions dispositive in constitutional interpretation, such evidence, if properly representative, ${ }^{46}$ would be persuasive. But the Daniels decision expressly disclaims

Constitution Act, 1867, supra note 2, ss 91(29), 92(10) (interprovincial railways), 91(27) (criminal law and procedure), 91(7) (defence and military matters).

See e.g. Reference re Wartime Leasehold Regulations, [1950] SCR 124; Reference re Anti-Inflation Act, [1976] 2 SCR 373.

43 We may never know why the parents of Confederation chose to allocate to the federal order legislative authority over "Indians, and Lands reserved for the Indians." As the trial judge in Daniels FC observed, the issue received no attention in the Confederation debates; the decision seems not to have attracted controversy (supra note 4 at paras 336-38). See also Douglas Sanders, "Prior Claims: Aboriginal People in the Constitution of Canada" in Stanley M Beck \& Ivan Bernier, eds, Canada and the New Constitution: The Unfinished Agenda, vol 1 (Montreal: Institute for Research on Public Policy, 1983) 225 at 273, n 23. The more common explanation of section 91(24)'s provenance is that it bespeaks acknowledgement "that the more distant level of government would better protect Indians against the interests of local settlers" (Sanders, ibid at 238). See also UK, Report of the Parliamentary Select Committee on Aboriginal Tribes (British Settlements), reprinted, with comments, by the Aborigines Protection Society (Piccadilly: William Ball, Aldine Chambers, Paternoster Row, and Hatchard \& Son, 1837); Province of Canada, Journals of the Legislative Assembly, 2-3, vol 6 (2 June 1847-28 July 1847) at Appendix T; Peter W Hogg, Constitutional Law of Canada, vol 1, 5th ed (supplemental) (Toronto: Carswell, 2015) at 28-2; Kerry Wilkins, "Life Among the Ruins: Section 91(24) After Tsilhqot'in and Grassy Narrows" (2017) 55:1 Alta L Rev 91 at 96-98; Peter H Russell, Canada's Odyssey: A Country Based on Incomplete Conquests (Toronto: University of Toronto Press, 2017) at 87. The unanswered question is whether Métis would have been thought at the time of Confederation to need equivalent protection. In Blais, supra note 26, the Supreme Court concluded (at para 33) that the parties negotiating the Manitoba Natural Resources Transfer Agreement in the late 1920s considered the Métis "more independent and less in need of Crown protection than their Indian neighbours." Whether this was so as early as the mid-1860s is unresolved.

$44 \quad$ Daniels SCC, supra note 1 at para 24.

45 Ibid at para 33. The decision provides some examples (ibid at paras 24, 27-33).

46 From an evidentiary standpoint, it is awkward that the Supreme Court, which made use for one purpose in Daniels SCC (ibid at para 39) of the survey of the population in 1856-57 in territories under Hudson's Bay Company governance that was included in the UK, House of Commons, Report from the Select Committee on the Hudson's Bay Company Together with the Proceedings of the Committee, Minutes of Evidence, Appendix and Index (31 July and 11 August 1857), cited with approval in Reference re Eskimo, supra note 31 at 106-107, 123, neglected to mention that the survey enumerated "Whites and half-breeds in Hudson's Bay Territory" separately from the "Total Indians" counted (Reference re Eskimo, ibid at 107) or that it had itself cited this enumeration as proof that "the "Whites and halfbreeds' were viewed as an identifiable group, separate and distinct from the Indians" (Blais, supra note 26 at para 27). 
reliance on this originalist approach to division of powers issues, agreeing with the Reference re Same Sex Marriage that reliance on framers' intentions is inappropriate for "a head of power which must continually adapt to cover new realities." 47 This, then, cannot have been the Supreme Court's reason for calling attention to pre- and early post-Confederation usage and to federal legislative policy.

Alternatively, the Daniels decision may have documented previous federal legislative practice as regards Métis (and non-status Indians) ${ }^{48}$ in the belief that such practice substantiates federal legislative authority. "Not only has the federal government legislated over Métis as "Indians," Justice Abella, who wrote for a unanimous court, observed after citing examples, ${ }^{49}$ "but it appears to have done so in the belief it was acting within its constitutional authority." 50

It is indeed peculiar that Canada would deny in Daniels having legislative authority it had earlier purported to use. One senses behind the Supreme Court's response a notion akin to estoppel: that Canada, in these circumstances, should not be allowed to disclaim jurisdiction. ${ }^{51}$ In proceedings such as Daniels, this notion has some appeal. But this is not, and with respect cannot be, how division of powers jurisprudence works. When someone puts the scope of federal authority in issue, the answer cannot be simply that the federal order believed "it was acting within its constitutional authority." Inferring federal authority from untested examples of federal legislative practice begs the very question at issue; on that approach, no federal law need ever be invalid. ${ }^{52}$ The limits on federal (or provincial) legislative authority - especially those on exclusive authority — operate, necessarily, independent of the laws that federal (or provincial) legislatures happen to enact. ${ }^{53}$ The integrity of constitutional adjudication depends on it. In a federal system, neither order of government gets to determine, just by believing (or, as here, disclaiming), the permissible scope of its own legislative authority.

\section{Constitutional Anomaly}

The Supreme Court's third reason for assigning Métis to federal legislative authority was to align section 91(24) of the Constitution Act, 1867 with section 35 of the Constitution Act,

Daniels SCC, supra note 1 at para 44, quoting with approval Reference re Same Sex Marriage, 2004 SCC 79 at para 30 .

See note 29 above and accompanying text.

Daniels SCC, supra note 1 at paras 27-32.

Ibid at para 33. See also ibid at para 27: "[C]ontrary to its position in this case, the federal government has at times assumed that it could legislate over Métis as "Indians."

Compare Schachter v Canada, [1992] 2 SCR 679 at 695, where the Supreme Court scolded Canada for conceding that its legislation infringed unjustifiably section 15 of the Charter, choosing to contest the appeal exclusively on the issue of remedy.

According to an old Burns \& Allen radio skit, Gracie's brother, asked to find out what percentage of households in town had telephones, conducted the survey by picking numbers at random from the phone book. "It was the strangest thing," Gracie said. "Everybody he called had one."

By way of example, Parliament repeatedly strove in the early days of Confederation to regulate the insurance industry, each time almost certainly "in the belief that it was acting within its constitutional authority." It tried, among other things, companies legislation, criminal sanctions, and taxation measures. Four times these measures came before the Privy Council; four times the Privy Council deemed them invalid incursions on exclusive provincial legislative authority: see Citizens Insurance Company v Parsons, [1881] UKPC 49; Canada (AG) v Alberta (AG), [1916] UKPC 12; Ontario (AG) $\checkmark$ Reciprocal Insurers, [1924] UKPC 5; Re Insurance Act and Special War Revenue Act (1931), [1932] 1 DLR 97 (PC). 
1982. ${ }^{54}$ Section 35 recognizes and affirms "[t]he existing aboriginal and treaty rights of the aboriginal peoples of Canada"; the phrase "aboriginal peoples of Canada" includes Indian, Inuit, and Métis peoples. ${ }^{55} \mathrm{We}$ already know that Inuit come within exclusive federal legislative authority ${ }^{56}$ and Canada has conceded that section 91(24) includes non-status Indians ${ }^{57}$ It would, therefore, the decision concluded, "be constitutionally anomalous ... for the Métis to be the only Aboriginal people to be recognized and included in s. 35 yet excluded from the constitutional scope of s. 91(24)." 58

Ideally, of course, the Constitution will be a harmonious whole whose interpretation generates fair and sensible results. But anomaly is often in the eye of the beholder. Even as it insisted in Daniels that section 91(24) aligns with section 35, for example, the Supreme Court felt free to define "Métis" under section 91(24) more broadly than under section $35 ;{ }^{59}$ some section 91(24) Métis are, therefore, by definition, ineligible for protection under section 35. If that problematic distinction is constitutionally defensible, it is so despite the appearance of anomaly.

As it happens, Canadian constitutional jurisprudence has been quite tolerant of anomaly. We know, for example, that the federal order has exclusive authority to accept by treaty surrenders of "Indians" " interests in land ${ }^{60}$ but has no constitutional authority (except perhaps in the prairie provinces) to create reserves from provincial Crown land in fulfillment of its treaty promises. ${ }^{61}$ And it is at least somewhat peculiar for Métis to count as "Indians" under section $91(24)^{62}$ but not under natural resources transfer agreements given constitutional effect by the Constitution Act, $1930 .^{63}$

Avoidance of anomaly, therefore, is at most desirable, not compulsory, in Canadian constitutional interpretation. Sometimes there is sufficient reason to insist upon a result that seems anomalous. (And not everyone, it seems, finds the same results anomalous.) The most one can do by pointing to a genuine anomaly is shift the burden of persuasion to the party disposed to advocate for tolerance of it.

“[I]n R. v. Sparrow ... this Court noted that ss. 35 and 91(24) should be read together" (Daniels SCC, supra note 1 at para 34 [citations omitted], citing with approval $R v$ Sparrow, [1990] 1 SCR 1075 at 1109 [Sparrow]). Here is the relevant passage from Sparrow, ibid:

Rights that are recognized and affirmed are not absolute. Federal legislative powers continue, including, of course, the right to legislate with respect to Indians pursuant to s. 91(24) of the Constitution Act, 1867. These powers must, however, now be read together with s. 35(1). In other words, federal power must be reconciled with federal duty and the best way to achieve that reconciliation is to demand the justification of any government regulation that infringes upon or denies aboriginal rights.

Section 35, according to Sparrow, limits the permissible exercise of the legislative authority already available under section 91, including section 91(24), of the Constitution Act, 1867. Sparrow does not purport to define or configure the scope of that pre-existing federal authority.

Constitution Act, 1982, supra note 22, ss 35(1)-(2).

See note 31 above and accompanying text.

Daniels SCC, supra note 1 at para 20 . See note 29 above and accompanying text.

Daniels SCC, ibid at para 35.

Ibid at paras 47-49.

Delgamuukw v British Columbia, [1997] 3 SCR 1010 at para 175.

See notes 26-27 above and accompanying text.

Daniels SCC, supra note 1 at para 50.

Blais, supra note 26 at para 42 . See generally note 26 above. 


\section{RECONCILIATION}

Here is the final thought that Daniels offers in support of the first declaration:

The constitutional changes [such as section 35's enactment], the apologies for historic wrongs, a growing appreciation that Aboriginal and non-Aboriginal people are partners in Confederation, the Report of the Royal Commission on Aboriginal Peoples, and the Final Report of the Truth and Reconciliation Commission of Canada, all indicate that reconciliation with all of Canada's Aboriginal peoples is Parliament's goal. ${ }^{64}$

Considered as history, this claim seems both false and irrelevant. False, because the history, since Confederation, of Parliament's legislative practice yields little evidence of interest in reconciliation with Indigenous peoples. If such reconciliation had indeed been "Parliament's goal," the federal apologies and the RCAP ${ }^{65}$ and $\mathrm{TRC}^{66}$ reports would probably not have been necessary. Irrelevant, because the goals that animate Parliament from time to time tell us nothing of value about the scope of Parliament's legislative authority. Regulating the business of insurance, for example, was a goal that Parliament repeatedly sought to achieve, but to no avail. ${ }^{67}$

Read more charitably, this passage is prescribing reconciliation with all Indigenous peoples, itself a constitutional imperative ${ }^{68}$ as a normative standard against which to measure Parliamentary conduct. On this view, we ought, if we can, to construe federal legislative authority broadly enough to enable Parliament to achieve that goal. But what does legislative authority have to do with reconciliation? We saw above that federal capacity to address Métis' and non-status peoples' interests and needs through program or service delivery and to accede to, negotiate, settle, or contest their claims of right does not depend on any particular view of section 91(24). ${ }^{69}$ With or without the first declaration, therefore, the federal order already has considerable capacity to reconcile with all of Canada's Indigenous peoples. Confirmation of its legislative authority over all Indigenous peoples would ensure its additional capacity to govern most, if not all, aspects of their lives, but ongoing close colonial supervision probably is not what many Indigenous peoples have in mind when they contemplate reconciliation. What more in the way of true reconciliation could result from the mere fact of such confirmation?

The Supreme Court does not say. And without the answer to that question, we do not know what, if anything, the first declaration has to do with achieving reconciliation. ${ }^{70}$ (As we shall see below, the first declaration, left unsupplemented, may, depending on what it

Daniels SCC, supra note 1 at para 37 [emphasis in original]. See also ibid at para 36.

Report of the Royal Commission on Aboriginal Peoples (Ottawa: Canada Communication Group, 1996). The Final Report of the Truth and Reconciliation Commission of Canada (Montréal: McGill-Queen's University Press, 2015).

See note 53 above.

See e.g. Mikisew Cree First Nation v Canada (Minister of Canadian Heritage), 2005 SCC 69 at para 1 (" $[\mathrm{t}]$ he fundamental objective of the modern law of aboriginal and treaty rights is the reconciliation of aboriginal peoples and non-aboriginal peoples and their respective claims, interests and ambitions"); Beckman v Little Salmon/Carmacks First Nation, 2010 SCC 53 at para 10 ("[t]he reconciliation of Aboriginal and non-Aboriginal Canadians in a mutually respectful long-term relationship is the grand purpose of s. 35 of the Constitution Act, 1982").

See notes 19-27 above and accompanying text.

Except, again, that it has precluded Canada from continuing to pretend that it lacks capacity necessary to participate meaningfully in reconciliation efforts. 
means, complicate or even discourage provincial reconciliation initiatives.) Pending further clarification, the reconciliation imperative does not help us understand the constitutional reach of section $91(24)$.

\section{E. SUMMARY SO FAR}

The Daniels decision gives us no compelling reason to conclude that Métis, or even nonstatus Indians, are "Indians" for purposes of section 91(24). From this, of course, it does not follow that the Supreme Court got the answer wrong in finding that Canada's convenient doubts about its legislative authority were not justified. Better arguments in support of the first declaration do exist; they appear in interveners' written submissions in Daniels. ${ }^{71} \mathrm{~A}$ poorly supported conclusion is, however, more vulnerable to reconsideration than one whose jurisprudential foundation is more stable.

\section{What DANIELS DECIDED, AND WHY IT MATTERS}

The Supreme Court, as we have seen, granted the first declaration requested in Daniels. "Non-status Indians and Métis," it said, "are 'Indians' under s. 91(24)" of the Constitution Act, 1867.72 "The term 'Indian' or 'Indians' in the constitutional context," it added, "has two meanings: a broad meaning, as used in s. 91(24), that includes both Métis and Inuit and can be equated with the term 'aboriginal peoples of Canada' used in s. 35, and a narrower meaning that distinguishes Indian bands from other Aboriginal peoples."73 "They are all 'Indians' under s. 91(24)," therefore, "by virtue of the fact that they are all Aboriginal peoples." $" 74$

At an absolute minimum, this means that "the outer limits of the 'Indian' power under s. 91(24)"75 are expansive enough to accommodate federal "Indian" legislation substantially more inclusive than the current Indian Act - inclusive enough to apply to individuals who identify today as non-status Indians or Métis - or legislation that targets specifically Métis or Indians currently without status. Under the usual constitutional rules about federal paramountcy, such legislation, once in force, would displace any conflicting provisions in valid provincial legislation. ${ }^{76}$ But if that is all the first declaration in Daniels means, section 91(24) does not otherwise interfere either with provincial laws' application to Métis and nonstatus Indians or with provinces' own capacity to enact their own laws about such peoples. And on this view, we, like the Supreme Court in Daniels, ${ }^{77}$ need not concern ourselves too much with the task of identifying non-status Indians or Métis; such peoples are not necessarily "Indians" in any constitutionally relevant sense unless Parliament chooses to

71 See e.g. MNC Factum, supra note 25 at paras 10 (section 91(24) authority necessary for federal legislation implementing modern treaties with Indigenous groups located within provincial boundaries), 15 (only federal order can ensure uniform, coordinated legislative response to Métis communities whose rights and traditional territories cross provincial boundaries).

Daniels SCC, supra note 1 at para 50.

Ibid, at para 35.

Ibid at para 46.

Ibid at para 40 .

See most recently Alberta (Attorney General) v Moloney, 2015 SCC 51; Orphan Well Association v Grant Thornton Ltd, 2019 SCC 5.

See Daniels SCC, supra note 1 at paras 17, 46-47. 
characterize them as such. The need for identification arises only when someone challenges Parliament's choices.

The first declaration in Daniels could, however, mean substantially more than that. It could mean in addition that Métis and non-status Indians are (and always have been) "Indians" for division of powers purposes irrespective of how or whether Parliament legislates under section 91(24). Put differently, it could mean that federal legislative authority over non-status Indians and Métis is exclusive. Provincial capacity to govern matters within exclusive federal legislative authority is more limited, even if Parliament chooses never to use that authority. To ascertain with precision the reach of those limits, we would need a way of identifying, independent of any federal legislation, those ("all Aboriginal peoples") ${ }^{78}$ who qualify as section 91(24) "Indians." Such an inquiry could proceed, as the Supreme Court proposed, "on a case-by-case basis in the future," 79 but if its results were not to be random (or, worse, opportunistic), it would require resort to consistent criteria. Development of such criteria requires that we either refine considerably our current understanding of what makes someone Indian (irrespective of status), Inuit, or Métis, or ascertain independent of these labels who "Aboriginal peoples" are for division of powers purposes. Daniels rejected the option, suggested by several interveners ${ }^{80}$ of adopting for this purpose Indigenous communities' own membership rules and determinations; someone can qualify as Métis (or, presumably, as non-status Indian) under section 91(24) without "community acceptance." The Supreme Court has not yet offered a tenable alternative.

It can make a significant difference, therefore, how one construes the first declaration in Daniels.

The trial judge took the first declaration to be about exclusive federal legislative authority ${ }^{82}$ and granted it on that understanding. ${ }^{83}$ The Supreme Court said at the outset of Daniels that it "agree[d] generally with the trial judge." ${ }^{, 84}$ But neither it nor the Federal Court of Appeal explained what it thought the first declaration sought, or what it meant. Both Courts quoted, ${ }^{85}$ as if in passing, the constitutional language (which does impute exclusivity)

Ibid at para 46.

Ibid at para 47.

See ibid (Factum of the Intervener, the Assembly of First Nations at para 41, online: <www.scc-csc. $\mathrm{ca} /$ WebDocuments-DocumentsWeb/35945/FM105_Intervener_Assembly-of-First-Nations.pdf $>$ ); ibid (Factum of the Intervener, Chiefs of Ontario at paras 14-19); ibid (Factum of the Intervener, Métis Settlements General Council at paras 2, 14-19), online: <www.scc-csc.ca/WebDocuments-Documents Web/35945/FM065_Intervener_Chiefs-of-Ontario.pdf> [MSGC Factum]; ibid (Factum of the Intervener, Te'mexw Treaty Association at paras 19, 29, online: <www.scc-csc.ca/WebDocumentsDocumentsWeb/35945/FM095_Intervener_Temexw-Treaty-Association.pdf $>$ ).

Daniels SCC, ibid at paras $47-\overline{4} 9$.

See Daniels FC, supra note 4 at paras 68 ("the Plaintiffs assert the right for [Métis and non-status Indians] to be included as Indians under s 91(24) and subject to the exclusive jurisdiction of the federal government to make laws in relation to them"), 72 ("[t]he Plaintiffs ... seek to know whether they fall within that class of people in respect of whom Canada has the exclusive jurisdiction to make laws"), 526 ("[t]his is the first case in which this Court has been asked to determine whether Métis and non-status Indians are a 'matter' that 'comes within' the class of 'Indians' as provided in s 91(24). That provision vests in Parliament the exclusive power to make laws in relation to all matters coming within the class of subject 'Indians and Lands reserved for Indians"').

Ibid at paras 600-601.

Daniels SCC, supra note 1 at para 10 .

Ibid at para 3; Daniels FCA, supra note 4 at para 16. 
related to the first declaration, ${ }^{86}$ but neither said whether the legislative authority it was ascribing to Parliament was exclusive or merely sufficient, or whether it even recognized the relevance of the difference.

We must, therefore, look in the decision for clues about the first declaration's meaning. On one hand, Daniels sought explicitly to minimize its impact on provincial legislative authority:

But federal jurisdiction over Métis and non-status Indians does not mean that all provincial legislation pertaining to Métis and non-status Indians is inherently ultra vires. This Court has recognized that courts 'should favour, where possible, the ordinary operation of statutes enacted by both levels of government': Canadian Western Bankv. Alberta, [2007] 2 S.C.R. 3, at para. 37 (emphasis in original). Moreover, this Court has been clear that federal authority under s. 91(24) does not bar valid provincial schemes that do not impair the core of the 'Indian' power: NIL/TU,O Child and Family Services Society v. B.C. Government and Service Employees’ Union, [2010] 2 S.C.R. 696, at para. 3 . $^{87}$

And no wonder. Throughout its recent jurisprudence, the Supreme Court has sought not to marginalize, but to encourage and even require, provincial involvement with Indigenous peoples and the discipline of reconciliation. It has invoked the reconciliation imperative ${ }^{88}$ as readily in respect of provincial as in respect of federal initiatives ${ }^{89}$ It has insisted that both orders of government, federal and provincial, fulfill the Crown's obligations to Indigenous peoples when exercising Crown powers that affect them, even when those powers derive exclusively from federally negotiated treaties. ${ }^{90}$ And it has cleared the way for justified provincial interference with Indigenous peoples' existing Aboriginal and treaty rights, eliminating such protection as section $91(24)$ had been thought to afford such rights. ${ }^{91}$

On the other hand, none of these jurisprudential developments precludes the federal order from having at least a measure of exclusive legislative authority over non-status Indians and Métis. Neither does the passage from Daniels quoted just above. ${ }^{92}$ In essence, the latter reiterates the Supreme Court's own recent disposition to limit resort to interjurisdictional immunity. ${ }^{93}$ And the decision need not even have mentioned there "the core of the 'Indian'

"[I]t is hereby declared that (notwithstanding anything in this Act) the exclusive Legislative Authority of the Parliament of Canada extends to all Matters coming within the Classes of Subjects next hereinafter enumerated; that is to say, ... 24. Indians, and Lands reserved for the Indians" (Constitution Act, 1867, supra note 2, s 91).

Daniels SCC, supra note 1 at para 51.

See note 68 above and accompanying text.

See e.g. Haida Nation v British Columbia (Minister of Forests), 2004 SCC 73 at paras 32-33 [Haida] (provincial duty to consult Indigenous groups whose rights or claims are put a risk by proposed provincial conduct); Tsilhqot'in Nation v British Columbia, 2014 SCC 44 at paras 82, 87 [Tsilhqot'in] (provincial obligation to justify infringing Aboriginal title).

90 Grassy Narrows First Nation v Ontario (Natural Resources), 2014 SCC 48 at paras 35, 50 [Grassy Narrows].

${ }_{91}$ See Tsilhqot'in, supra note 89 at paras 128-52 (Aboriginal rights and title); Grassy Narrows, ibid at para 53 (treaty rights). For critical commentary on these decisions, see Kent McNeil, "Aboriginal Title and the Provinces After Tsilhqot'in Nation” (2015) 71 SCLR 67; Wilkins, supra note 43.

92 See quotation in text at note 87 above.

93 Interjurisdictional immunity, in brief, protects a "core" of exclusive federal legislative authority, and the matters found to come within it, even from inadvertent impairment resulting from provincial legislation known to be valid. See Canadian Western Bank v Alberta, 2007 SCC 22 at paras 32-68 [Canadian Western Bank] for the canonical contemporary approach. 
power" if exclusive federal legislative authority - that which lies within the core — were not at least in contemplation.

Other clues in Daniels support the view that the first declaration confirms exclusive federal legislative authority. In the first place, the Supreme Court took pains, overcoming its evident disinclination to comment on identity questions, ${ }^{94}$ to ensure that all those who identify as Métis, even unaffiliated ones, come within "Parliament's protective authority." But the only thing from which the very existence of "Parliament's protective authority" suffices to protect non-status Indians or Métis is provincial legislative interference, and it does that reliably only insofar as it is exclusive. Concurrent federal authority could be protective only if, and depending on how, Parliament chose to use it.

Another clue is even more compelling. The whole point of Daniels - the task that, in the Supreme Court's view, alone gave this proceeding "tangible practical utility" — was to end "a jurisdictional tug-of-war" 96 over Métis and non-status peoples and guarantee them "certainty and accountability" by determining which of the two orders of mainstream government has "constitutional responsibility" for them and for "an inadequate status quo." "[I]t is," Justice Abella concluded, "the federal government to whom they can turn," because "[n]on-status Indians and Métis are 'Indians' under s. 91(24)."98 But this inference is persuasive, this conclusion justifiable, only if section 91(24) equips the federal order, in relation to Métis and non-status peoples, with at least some constitutional capacity unavailable to the provinces. In a rational constitutional order, attribution of exclusive constitutional responsibility entails some measure of exclusive authority.

The better current view, then, is that Daniels declares "all Aboriginal peoples," including non-status Indians and Métis, to be "Indians" under exclusive federal legislative authority, regardless of whether or how Parliament elects to define that term in legislation. This does not mean that they are exempt altogether from the reach of valid provincial legislation; it merely puts them all on the same footing vis-à-vis such legislation. It means that the same constitutional rules - no more, no fewer - apply irrespective of any differences that otherwise exist among Indigenous peoples.

But among those constitutional rules is this one. If exclusive federal authority extends to "all Aboriginal peoples" (and to lands reserved for any of them), then the provinces have no power at all to enact legislation whose primary subject matter is any Aboriginal people (or, presumably, its lands, considered as such). Any provincial legislation found to have some core aspect of Aboriginality as its primary subject matter will be invalid. This does not preclude provinces from mentioning Indians (or Métis, Inuit, or non-status peoples) in legislation really about something else within provincial legislative authority $;^{99}$ neither does

See Daniels SCC, supra note 1 at paras 17, 47.

Ibid at paras 47-49.

Ibid at para 15. This is not quite the right analogy to capture the plight of the Daniels plaintiffs. The object of a tug-of-war is to pull the rope, and one's opponents, over to one's own side. The problem here was that neither side showed any interest in picking up the rope.

Ibid.

Ibid at para 50 .

Kitkatla Band v British Columbia (Minister of Small Business, Tourism and Culture), 2002 SCC 31 at para 66. 
it routinely exempt such peoples from the general application of such laws. ${ }^{100}$ It does, however, preclude them from setting out specifically to regulate matters within the core of exclusive federal authority.

Existing Supreme Court jurisprudence has populated the core of exclusive federal authority over "Indians" with matters relating to "Indianness," to "Indians qua Indians."101 Examples include, among others, "their Indian character ... their Indian identity and relationship," 102 Indian status and its necessary incidents, ${ }^{103}$ and "relationships within Indian families and reserve communities." 104 The core of exclusive federal power over "Lands reserved for the Indians" includes matters relating to possession, occupation, and disposition, ${ }^{105}$ and presumably also to use,${ }^{106}$ of First Nations' reserve lands. ${ }^{107}$ In the absence of contrary judicial authority, we now must assume that this catalogue of exclusive core federal matters pertains alike to "all Aboriginal peoples," including Métis and non-status Indians.

With this as background, consider Alberta's Metis Settlements Act, ${ }^{108}$ a statute devised and implemented in collaboration with the Alberta Métis. ${ }^{109}$ The MSA constitutes and incorporates as "settlements" several nominate Alberta Métis communities, provides for membership in and governance of those settlements, and sets aside lands within Alberta for their particular use. It is considerably more beneficial to Alberta Métis than any legislation Parliament has enacted. In Cunningham, a case about section 15 of the Charter (not the division of powers), the Supreme Court said repeatedly that the MSA's

object ... is to enhance Métis identity, culture and self-government through the establishment of a Métis land base. This is a special type of ameliorative program. Unlike many ameliorative programs, the object of the applies to section 91(24) "Indians" unless it is deemed to impair a matter known to come within the core: see note 93 above. The current "restrained" approach to interjurisdictional immunity prefers generally to reserve its use to situations already covered by precedent, and even then to look to it only as a last resort (Canadian Western Bank, supra note 93 at para 77). For recent criticism of this approach, see Kerry Wilkins, "Exclusively Yours: Reconsidering Interjurisdictional Immunity" (2019) 52:2 UBC L Rev 697.

See e.g. Dick $v R$, [1985] 2 SCR 309 at 320-21.

Natural Parents $v$ Superintendent of Child Welfare (1975), [1976] 2 SCR 751 at 763, Laskin CJC [Natural Parents], quoted with approval in Bell Canada $v$ Quebec (Commission de la Santé et de la Sécurité du Travail), [1988] 1 SCR 749 at 836.

Natural Parents, ibid at 760-61, Laskin CJC, 787, Beetz J, dissenting; Four B, supra note 19 at 1048; NIL/TU,O Child and Family Services Society v BC Government and Service Employees' Union, 2010 SCC 45 at paras 70-71, McLachlin CJC and Fish J [NIL/TU,O].

Canadian Western Bank, supra note 93 at para 61; NIL/TU,O, ibid at para 71, McLachlin CJC and Fish J. Compare Natural Parents, ibid at 761, Laskin CJC.

Derrickson v Derrickson, [1986] 1 SCR 285 at 296 [Derrickson]; Paul v Paul, [1986] 1 SCR 306; NIL/TU,O, ibid at para 71, McLachlin CJC and Fish J.

Derrickson, ibid at 295, quoting with approval KM Lysyk, "Constitutional Developments Relating to Indians and Indian Lands: An Overview," in Special Lectures of the Law Society of Upper Canada, 1978: The Constitution and the Future of Canada (Toronto: Richard De Boo, 1978) 201 at 227, n 49. See also Sechelt Indian Band v British Columbia (Manufactured Home Park Tenancy Act, Dispute Resolution Officer), 2013 BCCA 262 [Sechelt], leave to appeal to SCC refused, 35503 (23 October 2014) (provincial mobile home park legislation inapplicable to Sechelt fee simple (!) lands deemed by federal legislation to be "lands reserved for the Indians").

RSA 2000, c M-14, as amended [MSA].

See MSGC Factum, supra note 80 at paras 5-7; Daniels SCC, supra note 1 (Memorandum of Argument of the Intervener, Gift Lake Métis Settlement at para 14, online: $<$ www.scc-csc.ca/WebDocumentsDocumentsWeb/35945/FM060 Intervener Gift-Lake-M\%E9tis-Settlement.pdf $>$ [Gift Lake Factum]); Alberta (Aboriginal Affairs and Northern D̄evelopment) v Cunningham, 2011 SCC 37 at paras 14-19 [Cunningham]. 
program is not the direct conferral of benefits onto individuals within a particular group, but the strengthening of the identity of Métis as a group.... 110

The MSA, in other words, is really about the identity and character of the Alberta Métis, their community relationships, and the reservation of lands for their exclusive use and occupation. ${ }^{111}$ So characterized, it qualifies as an ameliorative program shielded from scrutiny under section $15(1)$ of the Charter. ${ }^{12}$ But these are exactly the kinds of objects already known to comprise the core of exclusive federal authority over "Indians, and Lands reserved for the Indians." ${ }^{113}$ If, as Daniels can be read most plausibly to suggest, that which is exclusive about federal legislative authority over "Indians, and Lands reserved for the Indians" applies without differentiation to "all Aboriginal peoples," then the MSA's validity is in serious doubt. This, again, would not be so if non-status Indians and Métis came only within the outer limits, not the core, of federal legislative authority under section 91(24). ${ }^{114}$ But that result, as explained above, would require a rationale different from the one the Supreme Court adopted for entertaining the first declaration on its merits. ${ }^{115}$

It is unfortunate that the Supreme Court in Daniels did not say more clearly, and consider more carefully, what it would mean to grant the first declaration. The stakes are high in the contest over its meaning.

110 Cunningham, ibid at para 60. See also ibid at paras $62,65,69$.

111 A statute's object or purpose is the same for division of powers purposes as it is for Charter purposes ( $R$ v Big M Drug Mart Ltd, [1985] 1 SCR 295 at 334-35).

112 Cunningham, supra note 109 at para 71. At issue in Cunningham was whether the MSA, section 75, which excluded most status Indians from eligibility for membership in Métis settlements, contravened section 15(1).

113 See notes 101-107 above and accompanying text.

114 In Gift Lake Métis Settlement v Alberta (Aboriginal Relations), 2019 ABCA 134 [Gift Lake], the Alberta Court of Appeal, despite accepting (at para 22) that Cunningham, supra note 109, had accurately characterized the purpose of the $M S A$, worked hard to conclude that the relevant $M S A$ provisions - the same provisions whose Charter compliance had been at issue in Cunningham - were, from a division of powers standpoint, valid and applicable provincial law. In the Court's view, the MSA "squarely falls within the [provincial] property and civil rights power" (Gift Lake, ibid at para 32). Métis settlement lands are not "lands reserved for Métis" because they do not meet the statutory definition of "reserve" in the Indian Act and because they "were transferred by Alberta to the Métis Settlements General Council in fee simple" (ibid at paras 27-28 [emphasis in original]). (But see Sechelt, supra note 107.) Although we now know from Daniels that Métis are indeed section 91(24) Indians, the decision continued, "Indians" are not the primary subject matter of the MSA. "The question in this appeal," the Court of Appeal said, "is whether Daniels automatically created broad and sweeping changes to existing laws regarding Métis, and in particular, whether the declaration results in an automatic finding that all provincial legislation regarding Métis is inherently ultra vires. In our view the Supreme Court did not go this far" (ibid at para 31), quoting with approval Daniels SCC, supra note 1 at para 51, quoted above in text at note 87 . Finally, the MSA's statutory definition of "Métis" does not, the Court said, impair any exclusive federal legislative authority to define "Indians" because "the MSA does not purport to define Métis in the larger constitutional sense or as it relates to federal benefits. The impugned provisions ... do not constrain, restrict or dictate to the federal government what qualifications or criteria it may choose in providing federal benefits to Métis people in Alberta or elsewhere under s. 91(24)" (ibid at para 40). This is a good, reassuring result for the Alberta Métis, but the Court's reasoning does distort almost beyond recognition the traditional test for constitutional validity and even the newer, much more restrained approach to interjurisdictional immunity. See notes $96-98$ above and accompanying text. 


\section{BUT to What EFFECT?}

The Daniels plaintiffs succeeded on the issue of legislative authority. All Indigenous peoples in Canada are "Indians" for purposes of section 91(24). ${ }^{116}$ Canada, therefore, has, at a minimum, ample legislative authority to make laws about Métis and non-status Indians.

But how has knowing this improved their circumstances? The Supreme Court, again, took itself in Daniels to be guaranteeing "certainty and accountability" by determining that "constitutional responsibility" for them lies with the federal order ${ }^{117}$ But what, exactly, does this mean? In what way, in what forum, can the successful plaintiffs hold the federal government meaningfully to account?

The decision does not say, and the answer is not obvious. The problem that animated the Daniels plaintiffs was, again, federal unresponsiveness to their needs, interests, rights, and claims, especially in comparison with status Indians. ${ }^{118}$ As shown above, ${ }^{119}$ the division of powers imposes no significant constraints on Canada's capacity to accommodate these concerns; at the Supreme Court, federal counsel conceded as much. ${ }^{120}$ Virtually anything the federal government chooses to do today in response to the circumstances of non-status Indians or Métis it could have done before and apart from Daniels. But more importantly, Canada, as a matter of law, need do nothing differently today, after judicial confirmation of its legislative authority over all Indigenous peoples, than it did before the Supreme Court granted the first declaration. ${ }^{121}$ The Constitution Act, 1867 distributes legislative powers, not constitutional duties. As federal counsel pointed out and the reasons for judgment acknowledged, there is no enforceable obligation on Parliament to legislate. ${ }^{122}$ (And there has been no new federal legislation since Daniels addressing the interests of Métis or non-status Indians.) ${ }^{123}$ Neither, surely, do conclusions about the division of powers impose any enforceable obligation on either order of government to explain to anyone why, or even if, it has chosen not to legislate, let alone to justify how it chooses to use, or not to use, its resources. Precisely what leverage, then, do Métis and non-status Indigenous peoples have over Canada today that they did not have before the decision in Daniels?

The implication seems to be that they may hold Canada (as opposed to the provinces) "to blame" in some generic non-legal sense for their predicament, focusing on the federal order such political pressure as they have in the hope of achieving better results. But how is this

116 Daniels SCC, supra note 1 at paras 6, 9-10, 20, 35, 38, 46, 50.

117 See notes 96-98 above and accompanying text.

118 See note 1 above and accompanying text.

119 See notes 18-27 above and accompanying text.

120 See note 23 above and accompanying text.

121 Canada's reply factum acknowledged this candidly. See Daniels SCC, supra note 1 (Factum of Respondents/Cross-Appellants in Reply to the Interveners at paras 2-4, online: $<$ www.scc-csc.ca/Web Documents-DocumentsWeb/35945/FM035 Respondents Her-Majesty-the-Queen-as-represented-by-

The-Minister-of-Indian-Affairs-and-Northern-Development-et-al Reply.pdf $>$ ).

122 Federal Factum, supra note 9 at paras 67-68; Daniels SCC, suprā note 1 at para 15

123 The arguable exception is An Act to amend the Indian Act in response to the Superior Court of Quebec decision in Descheneaux c. Canada (Procureur général), SC 2017, c 25, which amends the registration rules in the Indian Act to expand further the classes of Indians whose children inherit their Indian status automatically and reduces somewhat the number of Indians still without status. But that decision was a necessary response to Descheneaux c Canada (Procureur Général), 2015 QCCS 3555, which had held shortly before the hearing of the Daniels appeal that the previous status rules discriminated unjustifiably on the basis of sex, contrary to section 15(1) of the Charter. 
an improvement over the "inadequate status quo" of which the Supreme Court complained at the outset of Daniels, in which Métis and non-status Indians "found themselves having to rely more on noblesse oblige than on what is obliged by the Constitution"? ${ }^{124}$ Notice too that Daniels, by ascribing "accountability" only to the federal order, effectively excuses provinces from attending to the needs and concerns of their Métis and non-status Indian residents. As long as the provinces meet the constitutional obligations that arise in respect of existing or credibly asserted treaty and Aboriginal rights, ${ }^{125}$ they now seem free to ignore these groups, as such. The first declaration may even operate, politically speaking, to discourage provincial governments that would have wanted to be more forthcoming from doing so: especially, though not solely, if the federal legislative authority is indeed to some degree exclusive. ${ }^{126}$ None of this is especially good news for the appellants in Daniels.

In addition to the declaration confirming federal legislative authority over non-status Indians and Métis, the plaintiffs in Daniels sought declarations that the federal Crown owes them fiduciary duties (the second declaration) and must consult and negotiate with them about "their rights, interests and needs as Aboriginal peoples" (the third declaration). ${ }^{127}$ The second declaration was necessary, the appellants argued, because Canada has consistently preferred its own interests to those of Métis and non-status Indians. They needed the third declaration, they said, because the federal Crown has relied on prosecution, not negotiation, in identifying their constitutional rights. ${ }^{128}$

The Supreme Court declined to grant either of these declarations. Both, it held, lack practical utility; they are redundant, merely restating existing law. We already know, it said, that the federal Crown is in a fiduciary relationship with Indigenous peoples, including Métis. ${ }^{129}$ And Supreme Court jurisprudence "already recognize[s] a context-specific duty to negotiate when Aboriginal rights are engaged." 130

This is not inaccurate. And from a certain angle, it can even look like a victory for the appellants: a confirmation that their view of the law on these issues is, at a fairly high level of generality, correct. But from the standpoint of the project the Supreme Court undertook in Daniels, clarifying Crown accountability "for an inadequate status quo," 131 it is deeply unfortunate. The inadequacies identified in the status quo for Métis and non-status Indians subsist, after all, in significant part because the existing law — that which we are said already to know — has itself been insufficient to correct for them. The pattern of federal indifference about which the Daniels plaintiffs complained had continued despite the precedents Justice Abella cited in deeming redundant the second and third proposed declarations. Reducing these proposed declarations to mere restatements of settled law surrenders to, instead of redresses, the acknowledged condition of inadequacy. 
This deserves elaboration. The prayer for the second declaration sought confirmation not, as the Supreme Court implied, of a federal fiduciary relationship with non-status Indians and Métis but of federal fiduciary duties to them. There is a difference. Calling a relationship "fiduciary" does create an expectation that one of its parties will have at least some fiduciary obligation to the other but, on its own, tells us nothing useful about that obligation: what it might require or when and how it might arise. A focus on the obligation would have been especially helpful in light of Manitoba Metis Federation, ${ }^{132}$ which had raised doubts about the existence of federal fiduciary obligations to Métis, in particular. The fact that the Red River Métis - arguably the paradigm historical Métis settlement — "used and held land individually, rather than communally, and permitted alienation," the Supreme Court said there, disqualified their interests in those lands from attracting Crown fiduciary obligations, ${ }^{133}$ even though, at the relevant time, the Crown did have discretionary control over those interests. ${ }^{134}$ Only "a communal Aboriginal interest in the land that is integral to the nature of the Métis distinctive community and their relationship to the land," it added, is capable of attracting such obligations. ${ }^{135}$ This will not be an easy test for other Métis communities to meet. It would have been helpful for the Daniels decision, in discussing the second declaration, to address this jurisprudence, to suggest what kinds of Métis interests might elicit enforceable Crown fiduciary obligations (and therefore provide the basis for a fiduciary relationship), and to indicate how the existence of such a relationship contributes to meaningful federal Crown accountability to non-status Indians and Métis.

In its brief discussion of the proposed third declaration, Daniels correctly called attention to previous decisions that had mentioned a Crown duty to negotiate claims of Aboriginal right. ${ }^{136}$ These precedents, however, provide, at best, only part of the clarification requested in the third declaration; they do not consider whether Canada has a concomitant duty to negotiate with Métis and non-status Indians about those of their "interests and needs" that are not rights, and they do not say specifically whether the Crown's acknowledged duty to

Manitoba Metis Federation Inc v Canada (Attorney General), 2013 SCC 14 [MMF].

Ibid at paras 56,59. Also disqualified are "Aboriginal interest[s] in land ... established by treaty, or, by extension, legislation" (ibid at para 58).

Ibid at para 52.

Ibid at para 53

Daniels SCC, supra note 1 at para 56. Examples include Haida, supra note 89 at para 25, quoted with approval in Rio Tinto Alcan Inc v Carrier Sekani Tribal Council, 2010 SCC 43 at para 32 [Rio Tinto] (" $[\mathrm{t}] \mathrm{h}$ honour of the Crown requires that [potential (unproved) Aboriginal] rights be determined, recognized and respected. This, in turn, requires the Crown, acting honourably, to participate in processes of negotiation"); Taku River Tlingit First Nation v British Columbia (Project Assessment Director), 2004 SCC 74 at para 24, quoted with approval in MMF, supra note 132 at para 66 ("[s]ection $35(1)$ has, as one of its purposes, negotiation of just settlement of Aboriginal claims"); Rio Tinto, ibid at para 32 (the Crown's duty to consult "is a corollary of the Crown's obligation to achieve the just settlement of Aboriginal claims through the treaty process"); MMF, ibid at para 73 ("[t]he honour of the Crown governs treaty-making and implementation ... leading to requirements such as honourable negotiation and the avoidance of the appearance of sharp dealing" [citations omitted]); Tsilhqot'in, supra note 89 at para 17, citing with approval Haida, ibid at para 25 ("the Crown had not only a moral duty, but a legal duty to negotiate in good faith to resolve land claims"); Tsilhqot'in, ibid at para 18 ("[t]he jurisprudence ... establishes [that] ... Governments are under a legal duty to negotiate in good faith to resolve claims to ancestral lands"). Daniels SCC also mentions in this context (ibid at para 56) $R v$ Powley, 2003 SCC 43 [Powley]. Powley's only references to negotiation, however, concern either historical events involving negotiations or Crown negotiation policy (ibid at paras 39-40) or the benefits of productive future negotiation about Métis' hunting rights (ibid at para 50). Nothing in Powley suggests that the Crown has a duty to negotiate. 
consult Indigenous peoples extends alike to Métis and non-status Indians. ${ }^{137}$ And none of them says anything that would assist an Indigenous party in attempting to enforce a Crown duty to negotiate about asserted or established Aboriginal rights. "The existing law" does not prescribe what triggers such a duty (when the Crown must agree (or offer) to negotiate), what standard of conduct "honourable negotiation" and "good faith" require of the Crown in negotiations, or what sanction or remedy is available when the Crown breaches the duty. This is not altogether surprising. None of the earlier cases featured allegations that the Crown was refusing to negotiate or was misbehaving in its conduct of any negotiations. In none of these decisions, therefore, did the Supreme Court need to say anything about possible Crown negotiation duties.

Daniels, on the other hand, dealt specifically with the federal Crown's alleged disinclination to negotiate about Métis' and non-status Indians' claims of right. That appeal gave the Supreme Court a chance to indicate when and how a constitutional duty to negotiate would operate: to tell Métis, non-status, and perhaps other Indigenous communities what they are entitled to expect from the Crown, and when. Instead, it recycled observations made in obiter in earlier jurisprudence: observations that by its own reckoning had not been enough to prompt Canada to accept its "constitutional responsibility" for an "inadequate status quo." Faced with the mere idea of a duty to negotiate about Indigenous claims of right, articulated only in the most general of terms in proceedings that did not engage or challenge Crown negotiation practice, the federal Crown, acting reasonably, could feel free, if it chose, to continue with business as usual. It was far from clear whether or how such a duty would ever be enforced. And even if it did prove enforceable in principle, there was ample scope for Canada to seek to convince the courts in a given case that the duty did not arise or, if it did, that the Crown had not contravened it. Nothing in Daniels required federal lawyers to change their legal advice about negotiating with Métis or non-status Indians.

In fairness, the appellants did not give the Supreme Court much to work with in respect of the latter two declarations. They did not, for example, seek to ascribe particular fiduciary obligations to Canada in respect of Métis or non-status Indians, or to argue that federal indifference to their situation constituted a breach of such obligations. Neither did they propose a view about when a federal duty to negotiate might arise, what it might require, or what the consequences should be for breach of it. These omissions compromised, perhaps fatally, the arguments in support of those two declarations. They left the Supreme Court without guidance from the parties about whether and how to articulate any relevant, enforceable obligations. They might well have suggested to it, too, that the appellants ascribed little importance to the second and third declarations. Considerations such as these help explain the judges' apparent lack of interest in those declarations.

But pause briefly to consider the irony of this. What made the Daniels appeal justiciable, in the Supreme Court's view, was the need to hold some Crown government "accountable

137 Almost certainly it does, but there is no Supreme Court of Canada jurisprudence, and very little from appellate courts, about this issue. In Newfoundland \& Labrador v Labrador Métis Nation, 2007 NLCA 75, the Newfoundland and Labrador Court of Appeal proceeded on the unexpressed assumption that the Crown does owe consultation duties to Métis communities in otherwise appropriate circumstances. Kane $v$ Lac Pelletier (Rural Municipality of) No 107, 2009 SKQB 348; Enge v Mandeville, 2013 NWTSC 33 do so, as well. $R v$ Kelley, 2007 ABQB 41 held that the duty to consult does extend to Métis. 
for an inadequate status quo" in respect of non-status Indians and Métis: to ascribe to the federal or the provincial order "constitutional responsibility" for their predicament. The declaration it granted, however, purported to clarify the relevant legislative authority but did nothing to illuminate what the accountability it was ascribing required of the Crown or what recourse it might offer the Daniels appellants. On the other hand, the two proposed declarations that Daniels deemed insufficiently useful, and withheld, could have given some enforceable content to this notion of constitutional responsibility and equipped the appellants with possible remedies when the Crown fell short of the relevant standard. What is wrong with this picture?

\section{Conclusion}

For non-status Indians and Métis, Daniels is an important symbolic victory, rewarding the appellants' perseverance despite repeated federal attempts to derail the proceedings. Not only that, it precludes the federal government from continuing to deny its constitutional capacity to address co-operatively their needs, rights, interests, and claims. In this instance, such denials were from the outset demonstrably bogus; little if any of that which non-status Indians and Métis were seeking required resort to legislative authority. In a different instance, though, that might not be so. A government's capacity to respond to another situation might well depend on the presence or absence of legislative authority. In such a case, because of Daniels, one need no longer accept at face value the government's disclaimer of capacity to respond as requested. There now is a way of testing such protestations in the courts even in the absence of legislation. And that is a good, constructive advance.

Unfortunately, it is just about the only good news one can find in Daniels, even, perhaps especially, for Métis and non-status Indians. The conclusion expressed in the first declaration — that non-status Indians and Métis are "Indians" for the purposes of section 91(24) — is intuitively plausible and quite possibly sound, but the reasoning by which the Supreme Court has reached it is sufficiently weak to encourage further inquiry into its soundness. The decision never says clearly what it means by the first declaration: whether Métis and nonstatus Indians are merely among those that Parliament may elect to deal with as "Indians," or whether federal legislative authority over them is exclusive, even if Parliament chooses never to use it. The former view allows us to defer the difficult questions of identification and has substantially fewer consequences for provincial legislative authority, but only the latter view coexists compatibly with Justice Abella's ascription of "constitutional responsibility" specifically to the federal order of government. Adoption of the latter view requires that we be able to identify, independent of any legislation, those within exclusive federal legislative authority over "Indians." It also casts into doubt the validity of existing beneficial provincial Métis legislation. Further litigation will almost certainly now be necessary to resolve these difficult constitutional issues. ${ }^{138}$

Finally, Daniels, after insisting on the importance of ascertaining which order of government is accountable to non-status Indians and Métis and determining that "it is the 
federal government to whom they can turn," ${ }^{139}$ offers them no real assurance of greater attentiveness to their plight from the federal government (and appears to excuse - perhaps even discourage - provinces from taking any particular interest in them). There is little or nothing that Canada can do for them in the wake of Daniels that it could not have done before, without knowing the answer to the question about its legislative authority, and confirmation of federal legislative authority over them generates, as far as we know, no fresh enforceable obligations on Canada to act differently. Having declined the opportunity to explicate its notion of accountability with reference to fiduciary or negotiation duties, the Supreme Court left the Daniels appellants with no effective remedies for their complaints.

After 17 years of hard-fought litigation, they deserved better. 